Impact Factor: 4.845(SJIF) Research Journal Of English (RJOE) Vol-5, Issue-2, 2020

www.rjoe.org.in

An International Peer-Reviewed English Journal

ISSN: 2456-2696

Indexed in: International Citation Indexing (ICI), International Scientific Indexing (ISI), Directory of Research Journal Indexing (DRJI) Google Scholar \& Cosmos.

\title{
HOW IS INDIA OVERCOMING THE PRESENT GROWING WESTERNIZATION
}

\author{
Kakarla Sai Mitravinda \\ Bachelors in Science (Statistics), P S G College of Arts and Science,Bharathiyar \\ University, Coimabatore,India :mitrasureshkumar9@gmail.com
}

\begin{abstract}
India, a subcontinent in Asia is one of the finest country having diverse culture, ethics and heritage. Westernization is slowly attacking each country and India is no exception. This paper is about how India is getting back its culture, traditions and customs from growing westernization and what they are doing; A short analysis on growing use of Swadeshi goods.
\end{abstract}

Keywords: India, culture, westernization, Swadeshi Goods, books

\section{Introduction:}

Our earth is believed to be formed 4.5 billion years ago. 335 million years ago, the world was a big landmass known as Pangaea. Slowly, the landmass started drifting apart and so the people. The people formed different cultures, ethics and morals according to the places they lived that paved way for the four main civilizations- Indus valley civilization, Egyptian civilization, Mesopotamian civilization and the Chinese civilization. India is a direct descendant of the Indus Valley civilization. Thus Indian culture dates back to 5500 BCE.

The Indian culture is one of the oldest and richest cultures, having a long history and is proud to be called as one of the ancient heritages. There are many festivals and celebrations which take place in India every year. India has a population of more than 1 billion who follow different cultures, celebrate different festivals and talk in diverse languages. But Indian culture is now being attacked by westernization and everything is slowly changing and is becoming modern.

\section{Past scenario:}

The impact of Westernization on the young Indians has brought the following changes that Indians have been doing for ages.

\subsection{Religious culture:}

India is the only country that gives nativity for all the religions regardless of their caste, creed and origin. Though India is a multicultural country, the government provides all the 
Impact Factor: 4.845(SJIF) Research Journal Of English (RJOE) Vol-5, Issue-2, 2020

www.rjoe.org.in

An International Peer-Reviewed English Journal

ISSN: 2456-2696

Indexed in: International Citation Indexing (ICI), International Scientific Indexing (ISI), Directory of Research Journal Indexing (DRJI) Google Scholar \& Cosmos.

benefits to all of the religions (see fig 1). The present generation who are devout for their religion, believe that they have a wide range of knowledge about their religion but alas! Their knowledge about their religion (its origin, the chanting mantras and so on) is very less when compared to their previous generations. They are completely ignorant of what they should know. If this goes on, our future generations might not have anything to know about the religion and thereby religions will completely vanish.

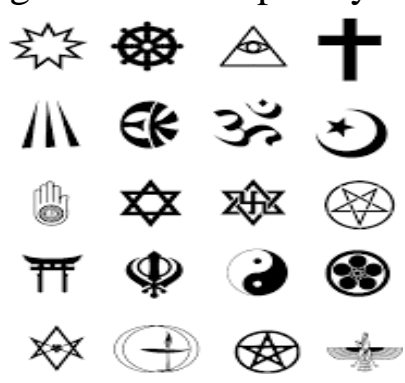

Fig 1: Religions in India

\subsection{Language:}

In India, there are in excess of 720 dialects (see fig 2) spoken. But, many of these mother tongue languages have started fading. Naturally, to get a good job, we must know the universal language. So people today are focusing on English and are completely ignoring their mother tongue. So in future, we won't have any more mother tongue languages and universally we will have only one language.

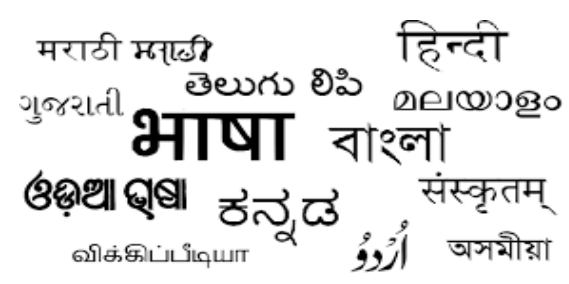

Fig 2: Languages in India

\subsection{Family structure:}

For ages, India is having the convention of the joint family framework (see fig 3).Joint family is when members of a family - parents, children, the children's spouses and their offspring, etc. - live together. Generally, the oldest male member is the head of the joint Indian family. That person makes all the important decisions and rules, and other family members are to abide them. In any case, these days the joint family framework is by all accounts imperiled in India. The possibility of a family unit has made the current age break of the well established customs. 


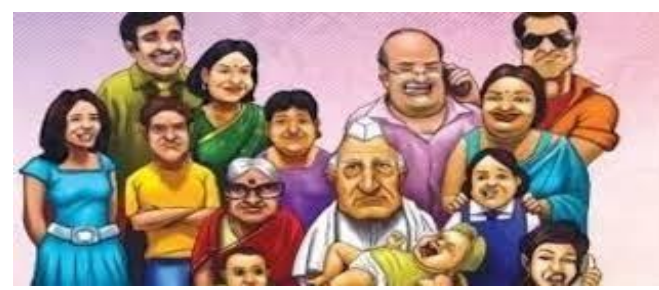

Fig 3: Joint Family System in India

\subsection{Marriages:}

Coming to marriages, Arranged marriages have for some time been the standard in Indian culture. Late investigations recommend that Indian culture is slanting endlessly from conventional orchestrated marriages. They find that the marriage slants in India are like patterns saw in the course of the most recent 40 years in China, Japan and different countries. The investigation found that fewer marriages are simply organized without assent and that most of reviewed Indian marriages are masterminded with assent. The rates of selforchestrated marriages are additionally expanding, especially in the urban pieces of India. The instances of separation have additionally developed impressively these years in India.

\subsection{Festivals:}

The western culture is impacting on Indian festivals (see fig 4) in many ways too. We Indians celebrate our festivals every year and enjoy them very much. Today, large numbers of people in our country are not celebrating Indian festivals but instead, are celebrating western cultured festivals. Also, in the Indian religion, no boy or girl is allowed to date each other however before marriage but now the present generation is breaking these ageold traditions and is celebrating Valentine's Day. If the present generations don't celebrate the festivals as our ancestors did then there won't be any part of our festivals for our future generation to know.

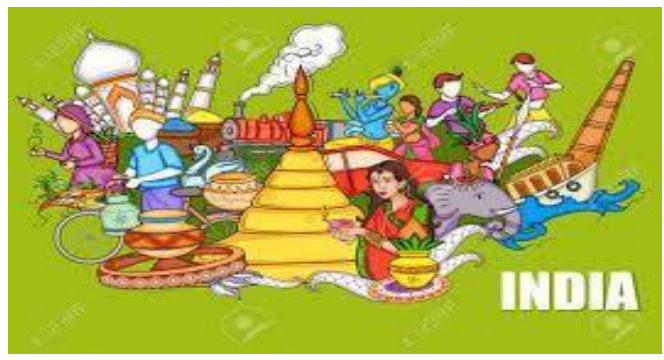

Fig 4: Indian Festivals

\subsection{Cuisine:}


Impact Factor: 4.845(SJIF) Research Journal Of English (RJOE) Vol-5, Issue-2, 2020 www.rjoe.org.in

An International Peer-Reviewed English Journal

ISSN: 2456-2696

Indexed in: International Citation Indexing (ICI), International Scientific Indexing (ISI), Directory of Research Journal Indexing (DRJI) Google Scholar \& Cosmos.

The food in India varies from house to house. Since in India we can find many religions and cultures their way of cooking foods and even eating habits differ. But now, the Indian plate has welcomed many western foods and Indian foods are being less popular in India, however, are becoming common in western countries. Western foods contain too much fat causing the obesity rate to increase. In some of the Indian religions, people are not allowed to eat pork or meat. But western foods have come in; many Indians are no longer respecting their religion and are eating things against their religion. This is causing the importance of the Indian religion to decrease and is changing many people's lifestyles. Today in India, there are more restaurants like KFC, or Mc Donald's compared to Indian restaurants.

Westernization has changed many people's lifestyles. There was no particular lifestyle which can be said as Indian. Most things have changed like respect to youthful ones and older folks, the significance of a family, marriage making, apparel, celebrations, nourishments, names, dialects and now individuals have gone to such a degree of getting plastic medical procedure to look progressively western. Individuals were changing themselves and were attempting to adjust like western individuals.

Westernization was likewise lessening the balance of ways of life in India. In the Indian culture, to visit a sanctuary, you should have the correct garments despite the fact that; it is stunning to see that at that point, numerous adolescents are dressing as present day individuals when entering a temple. Even the Namaste culture was no more. This conventional type of welcome is missing in the realm of business and in India's urban condition, where a handshake is a typical type of welcome. However, aside from business and corporate culture, we were in any event, welcoming the neighbors and our relatives similarly. (Saying Hi!)

Our Indian culture was certainly in the imperiled state. Be that as it may, we, the individuals of India, presently began making strides which are sparing India as well as setting the course of India in the correct track. We can safeguard Indian culture just on the off chance that you think about it totally.

\section{Swadeshi Products for promoting Indian culture:}

Our Prime Minister Shri.Narendra Modi has started promoting swadeshi products (i.e.) made in India goods from the time he has assumed the office from 2014.

"Products made in India, made by the hands of our citizens, carrying the fragrance of the sweat of our countrymen, can't we resolve to buy such things? I do not advocate this for a 
Impact Factor: 4.845(SJIF) Research Journal Of English (RJOE) Vol-5, Issue-2, 2020 www.rioe.org.in An International Peer-Reviewed English Journal

ISSN: 2456-2696

Indexed in: International Citation Indexing (ICI), International Scientific Indexing (ISI), Directory of Research Journal Indexing (DRJI) Google Scholar \& Cosmos.

long time, just till 2022, till the completion of 75 years of Independence," PM Modi said in his last 'Mann Ki Baat' programme for 2019.

\section{Here is a list of swadeshi products:}

4.1 Salt- Ankur, Saindha namak(Patanjali), Low Sodium \& Iron-4 Surya, Taja, Tara.

4.2 Tea _ Divya Peya,Tata,Brahmaputra,Assam,Taj Mahal,Brookebond

4.3 Ice Creams-Amul,Vadilal

4.4 Watches -Titan,HMT,Maxima,Ajantha

4.5 Electronics - Voltas,Videocon,Surya,orient,Crompton,Blue Star,Hawkins,Prestige

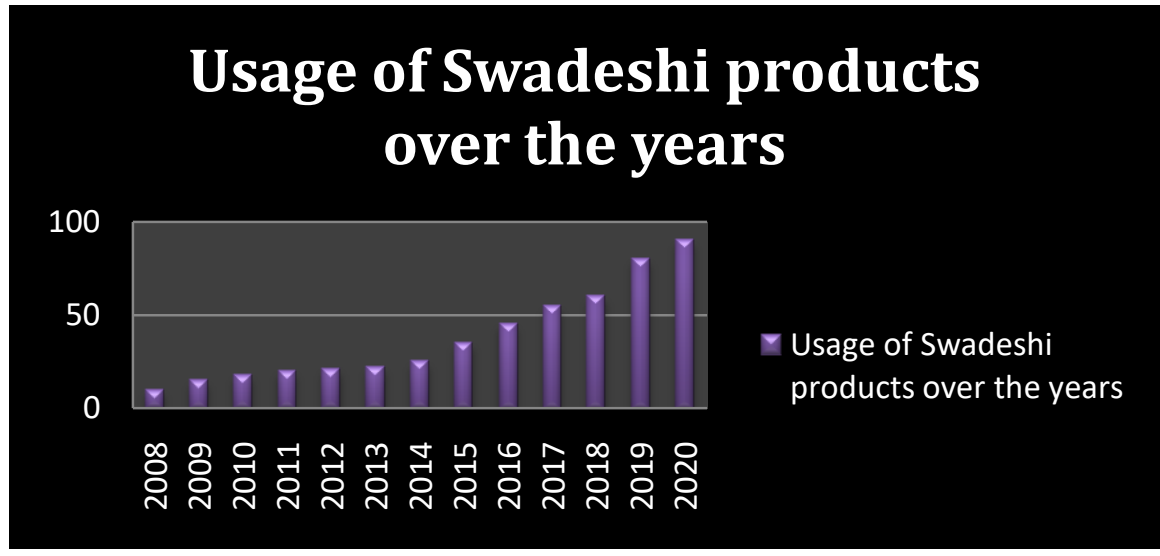

\section{Chart 1: Usage of swadeshi products over the years}

Books are important in everyone's life. A good book is like a good friend, the more you read it the more interesting and motivating your life becomes. A room without books is like a body without soul. But now people have developed the habit of reading. Books are been read extensively. People though aren't buying paperbacks many have moved to the kindle version.

\section{Here are some books which will help you gain a good insight into Indian culture.}

\subsection{Gateway to Indian culture by Chitra Soundar}

This is the book to peruse on the off chance that you might want a speedy manual for Indian culture and numerous parts of their lives. The Indian culture is a fiery mix of customs, conventions, religions and dialects, got from its various states, yet in addition its Muslim and European rulers. The home of the Himalayas, the Taj Mahal and the origination of Mahatma Gandhi, this nation has added to expressions, science and world food altogether.

There can be no single book that can guarantee a far reaching investigation of India, its kin, customs, religions and expressions. The bunch dialects, varieties in standings and customs, particular cooking styles, various types of old style and people works of art - all these make India a one of a kind report. As a feature of the Montage Culture arrangement, this book 
Impact Factor: 4.845(SJIF) Research Journal Of English (RJOE) Vol-5, Issue-2, 2020 www.rjoe.org.in

An International Peer-Reviewed English Journal

ISSN: 2456-2696

Indexed in: International Citation Indexing (ICI), International Scientific Indexing (ISI), Directory of Research Journal Indexing (DRJI) Google Scholar \& Cosmos.

offers a brief look at the sources of the Indian individuals and their strict and social traditions. The initial step to racial agreement and solidarity in any multi-racial society is to comprehend the subtleties of every network and their social structure. In this book, you can get some answers concerning the various Gods that Hindus go to, why Sikhs wear a turban and the purposes behind observing Deepavali and significantly more things that you never knew.

\subsection{Gateway to Indian classical literature by Jyotsna Bharti Poornima Pillai}

India having 5,000 years of history is a culture joined by assorted variety. India's scholarly conventions mirror her wonder and legacy. Today, magnificent works like Ramayana, Mahabharata and Panchathantra Tales are heard all through the world, having been envisioned in assorted artistic expressions. This book includes the most acclaimed artists and essayists who affected the general public as well as established altogether better approaches for deduction.

\subsection{Man-Eaters of Kumaon by Jim Corbett}

Peruse this book before heading off to the Jim Corbett National Park and you will appreciate each turn in the timberland. Safari aides and inn staff consistently have a lot of stories to enlighten the visitors regarding this legend.

This book shows him as the best 'safari-sahib' who was in determined quest for man-eaters. He discovered that specific creatures transform into man-eaters because of the consistent vanishing of the woods for their game chase, and consequently began a national park of sorts in those days to secure the powerless townspeople. The book shows his different encounters with the man-eaters. Horrifying killings are depicted now and again which will acquire dread our heart. A few stories depict him as a merciful tracker who is deferential of the regular habitat of India. This book depicts how rich India's widely varied vegetation can be.

\subsection{All roads lead to Ganga by Ruskin bond}

Ruskin Bond's adoration for the Himalayan life is unmistakably appeared in this book joins to everybody's heart when visiting the Himalayas. Delightfully wrote, Ruskin portrays the amazing magnificence and the grandness of the slopes and Ganga, India's holy waterway, through this superb romantic tale. He depicts the basic life in the mountains and has installed in his nostalgic anecdotes about the individuals he has gotten during his coexistence there. The spot has changed since the time he composed this book. Nowadays, to really observe and encounter the book he has composed, you lamentably need to go outside of these urban areas and towns.

\subsection{Nine Lives by William Dalrymple}

William Dalrymple is an incredible creator. Peruse any of his books and you will discover the exploration the writer has don't to compose his books. "Nine Lives" is an anecdote around nine individuals, otherworldly in their way. The creator shows how the lives of these 
Impact Factor: 4.845(SJIF) Research Journal Of English (RJOE) Vol-5, Issue-2, 2020 www.rjoe.org.in

An International Peer-Reviewed English Journal

ISSN: 2456-2696

Indexed in: International Citation Indexing (ICI), International Scientific Indexing (ISI), Directory of Research Journal Indexing (DRJI) Google Scholar \& Cosmos.

individuals changed and are being influenced by the modernization of India. Some of them are ignored; some of them must be 'low maintenance' god and the others are disregarded by society. This book is a token of why certain societies despite everything exist in our general public and open up our psyche to see these individuals under an alternate light.

\section{Conclusion}

Indian culture is something which brings the culture of different people together each one following their own with peace and harmony. So, in future when foreigners visit our country they must find it in the same way they found centuries back. Preserving Indian culture doesn't mean bringing the very age-old traditions that endangered the life of men and women. A culture is a true culture only when all the people who follow it should be happy and should enjoy.

Indian culture dates back to over 6000 years. Anything that is demonstrated by time in this way certainly has natural qualities that are valued and esteemed by Indians. By saving our way of life simply like our progenitors, the group of people yet to come would definitely know its worth.

The way of life that India has is what makes India stick out. We should allow this to proceed. In the event that we, the current age take the pledge of saving our way of life then India will keep on being multi-social, multi-ethnic and multi-religious society.

\section{Declarations}

7.1 Study limitations: None

7.2 Funding source: None

7.3 Competing Interest: None

\section{References:}

1. Chitra Soundar (2007), Gateway to Indian culture, Asiapac Books,pp 1-192. ISBN10: 9812293272

2. Jyotsna Bharti and Poornima Pillai(2005), Gateway to Indian classical literature, Asiapac books,pp 1-152.ISBN-10: 9812294279

3. Jim Corbett ( 1944), Man Eaters of Kumaon, Oxford University Press,pp1-228,ISBN10: 0195622553

4. Ruskin bond (2007 ),All roads lead to Ganga ,Rupa publications,pp1-128,ISBN-10: 9788129112132

5. William Dalrymple (2009), Nine Lives:In Search of sacred in modern India, Vintage,pp1-304,ISBN-10: 9780307474469

6. https://economictimes.indiatimes.com/news/politics-and-nation/mann-ki-baat-pmmodi-asks-people-to-promote-indigenousproducts/articleshow/73016513.cms?from $=\mathrm{mdr}$ 